\title{
Teaching in Hong Kong: Professionalization, Accountability and the State Paul Morris
}

\section{$\underline{\text { Abstract }}$}

This article traces the processes for encouraging and/or ensuring the accountability of teachers in Hong Kong. It is argued that, if examined historically, the nature of teacher accountability has been determined by the government, whose approach has been ambivalent and paradoxical. Up until the mid 1980s, through inertia and nondecisions, the government maintained the low level of professionalization of teaching. Subsequently, from the late 1980s onwards, it resisted and diluted attempts by the professional community to regulate itself. Most recently it has actively sought to introduce systems to allow the government to scrutinize teachers in an ostensible attempt to promote the level of teacher professionalism. These changes are analysed in terms of the differences between professionalism and professionalization, and with reference to the government's own legitimacy and the changing political context.

\section{$\underline{\text { Introduction }}$}

This article will examine the processes that have been developed to hold teachers accountable in Hong Kong since the mid 1960s which saw the emergence of a system of universal education leading to compulsory education up to Secondary 3 (age 15). 
The nature of teacher accountability necessitates on analysis of both the development and status of the teaching profession in Hong Kong.

The initial absence, and the more recent emergence, of processes for holding teachers accountable (and unaccountable), the status of the profession and the fate of attempts to develop systems of self-regulation have been strongly interconnected and influenced by the actions and inaction of the government. It is therefore necessary to locate the analysis of the current status of teacher accountability in a broader context, which has two key elements. Firstly, there are the antecedents that have served to define: the characteristics of teaching as an occupation, the professional status of the teaching force and, strongly associated with this, the role of teacher education as the primary gatekeeper to the profession. Secondly, and strongly interwoven with the above, is the government's own legitimacy and relationship with those elements of civil society that are directly linked to schooling, such as the agencies that run schools and the teachers' unions.

Accordingly, this paper initially reviews the situation prior to the return of Hong Kong's sovereignty to the People's Republic of China in 1997 as this has provided the antecedents from which the current situation has developed. Subsequently the post- 
handover situation is analysed. Before proceeding, it is necessary to undertake a brief clarification of the key concepts central to this paper. Accountability and professionalism/professionalization are concepts which have been extended in a variety of directions and sometimes in ways beyond their core meanings.

Teaching: accountability, professionalism and teacher education

Mulgan (2000) comments on the shifting meaning of the term 'accountability' and underlines the need for conceptual clarification.

That 'accountability' is a complex and chameleon-like term is now a commonplace of the public administration literature. A word which a few decades or so ago was used only rarely and with relatively restricted meaning now crops up everywhere performing all manner of analytical and rhetorical tasks and carrying most of the major burdens of democratic 'governance' (itself another conceptual newcomer).

Brown (1990, p.159) defines accountability as having to answer for one's actions, and particularly for the results of those actions. Jones' (1992) definition of accountability, as the process of being called to account to some authority for one's actions, catches the essence of the concept. Mulgan (2000) argues that if the concept has at its core the idea of being 'called to account', then this necessarily requires both some form of external scrutiny and the possibility of sanctions. The implications of this are that concepts of accountability which are based on an individual scrutinizing their own performance do not represent forms of accountability, but are more accurately described as forms of 'professional responsibility'. Therefore central to the debate about accountability is not the need for its existence, but rather its locus of control, as 
the critical question that arises is to whom teachers are expected to be accountable for their actions. If one views accountability as an obligation for any profession, then it would essentially involve an ongoing process undertaken by the professional community. If, however, there is not widespread trust in the competence and overall professionalism of teachers, and/or if the profession does not, or is not permitted to, hold its members accountable, then their performance will be increasingly monitored and judged by agencies established outside the profession - specifically and most notably by the state. Even where the process of accountability is undertaken within a profession, the power to both scrutinize members of the profession and use sanctions is ultimately delegated by the state. Throughout this article, the focus is on the former aspect of accountability, that is external scrutiny.

Professionalism is similarly a term with a variety of meanings - pest control firms, armies and crime syndicates have all appropriated it as a euphemism for efficiency, the provision of specialist services or the possession of a body of specialist knowledge. With regard to the nature and status of teaching as a profession, there is, according to Larson (1977), agreement that professions are characterized by a combination of the following general dimensions: a body of knowledge and techniques which professionals apply in their work; training to master such knowledge and skills; a service orientation; distinctive ethics, which justify the privilege of self regulation that society grants them; and an implicit comparison with other occupations, which highlights their autonomy and prestige. Eraut (1994) stresses that the key features of a profession involve a strong moral commitment to the needs of the client.

Within education the term professionalism is variously used to refer to the status of 
teaching as a profession (or professionalization); the extent to which individual teachers act in ways which are deemed to be professional; and the professional status of teacher education programmes, as a source of professional development, learning and certification.

Often these meanings are combined, or conflated, with the result that the goal becomes to simultaneously professionalize teaching (as a type of employment), teachers as individual actors and teacher education. It is important to distinguish between these three dimensions, as failure to do so results in a tendency to ignore both their interconnections and possible tensions. For example, teachers may be prepared as professionals to work in a context in which teaching is not perceived within the wider community to be a profession, or the community may expect teachers to act professionally but they still do not have the status of a profession. Within Hong Kong there is ample evidence (Cheung, 2001, Lo, 2000) indicating the high level of professionalism of individual teachers despite the fact that the profession itself has few of the characteristics associated with a strong profession. It is the latter sense which is the primary concern of this article.

Similarly, the struggles to improve the status of teaching as a profession, or the process of professionalization, around the world are matched by the ongoing struggle to improve the status of teacher education. However, teaching and teacher education have a long history of what the Holmes Group (1986) termed 'mutual impairment'. Teacher education has been seen as academically weak in universities and this undermines the status of teaching. In parallel, teaching has long been viewed as a low status occupation and often the object of public ridicule, sometimes initiated by governments. This has served to make it difficult to recruit the most able students to 
join the teaching profession. This process of mutual impairment has been accomplished by a tendency for each party to blame the other for the resulting problems of the status of teaching and student recruitment. Thus governments tend to stress that the success of reforms is dependent on the professionalism and standards of individual teachers and the quality of teacher education programmes. In turn teachers and teacher educators tend to focus on aspects of professionalization such as the perceived low status of teaching as a profession, the 'unprofessional' conditions of employment and the impact on morale and recruitment of politicians constantly criticizing teachers. A consequence of this process of mutual impairment and the differential emphases on professionalism and professionalization is that the implementation of school and curriculum improvement measures becomes a problem without a clear solution as key groups attribute the locus of the solution and blame elsewhere.

In Hong Kong there has been a growing tendency for the government to develop mechanisms to hold teachers accountable that are premised on a perception of a weak level of teacher professionalism in parallel with desire to avoid the professionalization of teaching. This is further analysed below, by examining the continuities and differences between the pre- and post-1997 handover periods that have emerged.

\section{The Hong Kong context prior to the change over from British colonial rule}

There are many very dedicated, caring and professionally minded teachers in schools in Hong Kong, but overall if we compare teaching to other professions (e.g. medicine and law, which require high standards of entry and exit, and are self-regulatory), or to countries with high levels of professionalization (e.g. Finland, Sweden and Japan) it is difficult to view it in any sense as possessing the characteristics of a strong profession 
(Morris and Williamson, 2000). Teaching in Hong Kong could, until recently, be defined in Etzioni's (1969) terms as a 'semi-profession':

Their training is shorter, their status is less legitimated, their right to privileged communication is less established, there is less of a body of specialized knowledge, and they have less autonomy from supervision or social control than the 'professions'(p. v).

There are a number of specific features that affect teaching in Hong Kong and have served to define its status and low level of professionalization:

- There are still no minimum entry requirements for people to obtain employment as teachers (except for kindergarten and PE teachers). Thus, for example, even in 2001 over 40 percent of those who obtained jobs as teachers had no professional qualifications (Lai, Ko and Li, 2001).

- In some subject areas, most notably English and Art, a very high proportion of teachers of those subjects had no background in studying the subject as a major within their degree programmes.

- Most teacher education courses have been provided in institutions that are outside the mainstream university sector and are thus perceived to have low status. Consequently they have had difficulty competing to recruit students especially following the expansion of the university sector.

- It is only very recently that the strong distinction between the status and qualifications of primary school teachers and secondary school teachers of non-academic subjects (such as Art, Music and PE) has begun to be raised to a level similar to that of secondary school teachers of academic subjects. Prior to 2003 primary teachers and secondary school teachers of cultural subjects were trained through sub-degree Certificate courses that involved either three 
years of study after Secondary 5 or two years after Secondary 7. Therefore, many primary teachers had not themselves completed secondary school and when they emerged from a 3-year college certificate, they had been trained to teach four school subjects, namely Chinese, English, Mathematics and General Studies. In reality, the level of subject depth for many teachers in each of these areas had only reached that of A-level equivalence, and for many teachers their level of English language proficiency was extremely low but they were expected by schools to teach English. Prior to 1994 their training took place in Colleges of Education run by the Civil Service. In contrast, teachers of most secondary school academic subjects (all subjects except PE, Art, Music and Technology) were university graduates and paid on a higher scale than the Certificate teachers.

- There has been no agency that serves to represent teachers professionally or to regulate teachers' professional behaviour. There are two significant bodies that represent the interests of teachers in Hong Kong, but these are both unions that are distinguishable by their affiliation to major political groupings. The largest and probably the strongest single union in Hong Kong is the Professional Teachers' Union (PTU), which was born as a result of a strike by Certificate teachers (non graduates) in 1972/1973 when the government attempted to delink their salaries from the civil service pay scale. The outcome was that the government had to back down. Since June $4^{\text {th }} 1989$ - the Tiananmen Square incident - the PTU operated in colonial times as a major source of opposition to the colonial government and since 1989 has been very strongly aligned with the main opposition to government, the Democratic Party (Cheng \& Wong, 1997). The other major body, the Federation of Education Workers, is far smaller in terms of its membership but is aligned with pro-Communist and 
mainland political groupings and perceived therefore as more pro-government. The outcome of this scenario is that the relationship between government and the teachers has often been highly politicised, especially given the absence of any body that focuses on promoting or protecting teaching as a profession.

The above conditions have all contributed to maintaining teaching as a low status occupation with few of the characteristics associated with a strong degree of professionalization. They have also been the primary reasons put forward by the government to justify its increased role in monitoring and evaluating teachers. Some of these features are now changing and these are addressed in a later section.

Similar conditions relating to the training and qualifications of teachers have previously operated elsewhere, especially in countries that were former British colonies. However, unlike the situation elsewhere, it was not until the 1990s in Hong Kong that overt attempts were made to enhance the status of teaching. The comparatively late actions to raise the status of teaching (e.g. by requiring minimum entry requirements and a degree) seem to arise from a number of motives:

- There was a signal failure to anticipate the impact on teacher education of the shift from an elite to a mass education system and the resulting growth of the university sector. Prior to the rapid expansion of higher education in the late 1980s, the former Colleges of Education were able to attract highly qualified school leavers as only around two or three percent of the relevant age group could secure places in local universities. This situation changed drastically when, by the early 1990s, the university sector, which excluded the colleges, had expanded to recruit 18 percent of the relevant age group and about another 
ten percent went on to study overseas. The result was that the academic standards of the intake to the Colleges declined markedly.

- There was in Hong Kong, as elsewhere, a strong view, especially among the policymaking elite, that teaching was a type of work that required no specialist expertise but merely required the technical skills of transmitting information to prepare pupils for public examinations. Kindergarten and primary school teaching in particular were characterized as 'women's work' that primarily involved caring for and minding young children. Further, many of those who were making decisions about education policy were reluctant to see the government lose its control of those institutions.

- Most importantly, in all areas of education policy the colonial government's overriding concern was to ensure that the system did not encourage any activities that might be subversive or destabilizing. Thus school curricula were depoliticised and focussed on far away places and times (Morris, 1997). After the teachers' strike of 1972 , which threatened the stability of the colonial government, and the emergence of the PTU, there was a great deal of caution about creating a more qualified, professionalized and potentially subversive teaching force.

The outcome of these influences was a form of reverse accountability insofar as the colonial government seemed unwilling to encourage the emergence of a professionalized teaching force and more accepting of a situation in which teachers were compliant, disunited and uncritical. Through inaction it effectively allowed the status quo to continue. Primary teachers were prepared through short sub-degree programmes in government-run colleges with a very strong technical orientation, while secondary schools were staffed by graduates, who often took a teaching job 
when the labour market was tight or while they searched for other employment. The government ensured thus that it was not faced with a more organised and professionalized teaching force.

The observation of the Visiting Panel (1982) was accurate and prescient:

... we are concerned with the lack of cohesion and indeed the absence of a sense of there being a teaching profession in Hong Kong as distinct from groups of teachers who work in particular schools. (p. 96)

The government's desire to avoid the emergence of a stronger teaching profession was most evident in its response to the attempts in the 1980s and 1990s by external advisors and some members of the teaching community, led by university academics, to develop a self-regulating profession. For a full account see Cheng \& Wong (1997). The Visiting Panel had first recommended the setting up of a teaching service (akin to a General Teaching Council) independent from the government that would promote and monitor the profession and would have powers of registration/deregistration.

The Education Commission, which operates as the main advisory body on education policy, in its second Report (ECR2, 1986) rejected this proposal and instead recommended the establishment of a Teachers Centre and publication of a voluntary Code of Practice, which would be designed to foster a sense of professionalism. These were implemented and a large committee elected by teachers and other education workers undertook the latter task. The Code for the Education Profession of Hong Kong (1990) was published after an extensive public consultation process, and was used as another opportunity to recommend the establishment of an independent professional entity, called a General Teaching Council, as a body to implement the code and maintain professional discipline. A proposal to this end was subsequently 
made, but again rejected by the Education Commission in its fifth Report (ECR5, 1992).

Instead the Commission counter-proposed that a Council on Professional Conduct in Education be established by the government's Education Department and recommended that its main role would be to advise the Director of Education in cases of dispute concerning misconduct. This Commission Report also resulted in the setting up of the Advisory Committee on Teacher Education and Qualifications (ACTEQ). This is the only formal body that is currently empowered to support the process of professionalization of teaching. However, it is a classic example of the government's instinct to rely on a top-down, bureaucratic and paternalistic approach. The government controls the Committee's membership and agenda, and it serves only in an advisory capacity.

The key elements of this saga of proposal and counter proposal were that whilst advocates from the profession desired to create a self-regulating and independent body with powers, the government's goal was to maintain control and avoid either the emergence of a potentially strong professional body or a potentially powerful body that might be taken over and politicised by the PTU and the PTU itself operated in a way which reinforced those concerns. The Education Commission was used to neutralize the quest for self-regulation and was willing to do so for two reasons. Firstly, there was a genuine concern that any representative body would be dominated and politicised by the PTU. Secondly, in the run up to ECR5 in 1993, the Commission 
was not willing to jeopardize the progress it had made in other areas of policy, especially that related to disestablishing the Colleges of Education, setting up the Hong Kong Institute of Education (HKIEd) as an autonomous tertiary institution, and the creation of about 30 percent graduate posts in primary schools. These policies were designed to strengthen the teaching profession and initially were strongly resisted by the government.

In many respects, the core issues and tensions were very similar to those evidenced elsewhere as governments and the teaching force compete to exercise control over the profession. As Ingvarson (2000) comments with regard to the Australian experience, governments will not relinquish control easily or voluntarily. To date, in Hong Kong, the idea of a General Teaching Council has re-emerged on the policy agenda and in 1997 the Education Commission set up a working party to pursue the issue. The outcome of this has not yet become clear.

The ways in which teachers were held accountable, albeit in its loosest sense of that concept, emerged not from the state or the professional community but from the various charitable and religious bodies that ran most of the schools and regulated them directly within the broader context described earlier (only about ten percent of schools are directly run by the government). The key aspects of that context were that 
the Government maintained direct control of both the nature of the curriculum and the system of public examinations. Teachers were employed by schools that competed vigorously to recruit and retain the most academically able pupils. The key element within this competition was the school's public examination results and the associated capacity to provide pupils access to higher levels of education, i.e. secondary or tertiary level. The examinations involved pupils studying curricula that had been carefully devised by the government to ensure a focus on matters academic and the avoidance of any content that might be viewed as politically sensitive or questioning the legitimacy of the government (Morris, 1996).

The combination of this highly competitive and exam-oriented system along with the strong central control of school curricula and a weak teaching profession, characterized by the absence of any entry requirements, resulted in a very effective but instrumental and narrow system of accountability. Teachers and pupils both worked hard in an attempt to succeed in the public examinations, which would decide both the pupil's future in the highly competitive educational system, where the chances of going on to higher education were strongly influenced by the kindergarten, primary and secondary schools attended, and the status of the individual teachers in schools. The resulting definition of the role of the teacher as primarily a coach of 
pupils preparing for external and decontextualized public examinations was reinforced by the fact that the vast majority of pupils would be taking their examinations in English and many of the teachers and pupils had a poor level of proficiency in that language. In effect teachers, especially those in secondary schools, were primarily judged by reference to and held accountable for the examination results of their pupils.

Whilst there were some post-war incidents where the government acted to remove teachers who were attempting to promote politically subversive ideas (see Sweeting, 1993), on the whole there was no formal system designed to appraise, monitor or regulate teachers. The overall picture was therefore one of an absence of any formal accountability by either the professional community or the government, and this occurred in an environment where there was a weak degree of professional autonomy and a very low level of professionalization amongst teachers. The accountability that did operate was of a generic nature and a by-product of a highly competitive examination-driven system.

The government thus effectively extended its laissez-faire economic policy to its relationships with schools and to the teaching profession except wherever a threat 
might emerge to its stability. Thus the riots of $1966 / 67$ saw the introduction of a number of measures to strengthen the government's control of schools and to deregister teachers who worked in the pro-communist patriotic schools (Sweeting, 1993). However, such threats were minimal after the late 1960s, when schools devoted themselves to the task of preparing pupils for public examinations.

\section{The present and future}

The post-handover government therefore inherited a system that was characterized by a low level of professionalization and the absence of any specific processes of either an internal or external nature to promote accountability. With the notable exception of the implementation of the recommendations of ECR5 to establish the Hong Kong Institute of Education (HKIEd) (formed from the merger and disestablishment of the Colleges of Education) and the acceptance that 30 percent of teachers in primary schools should in the long term be graduates, the colonial government had not actively attempted to enhance the professionalization of teaching.

Thus, on 1 July 1997, the system continued to prepare teachers for primary schools and cultural subjects through sub-degree courses, accepted students to train as teachers prior to their completing secondary schooling, and allowed many teachers to 
teach subjects they had not previously studied at an advanced level or received professional training. Whilst the creation of the HKIEd in 1994 had taken teacher education out of the civil service, it is still perceived as operating on the margins of the higher education sector, and currently is a non self-accrediting and sub-university level institution, despite being placed under the aegis of the University Grants Committee from 1996. This has served to maintain the low status of teaching (or as the Holmes Report described it the cycle of 'mutual impairment') and make it difficult for the main teacher education institution to recruit from the ranks of the most able students.

As schools competed both to recruit 'good' pupils and for their pupils to do well in the public examinations, there was a strong tendency to drop or reduce the time devoted to those school subjects that were viewed as low status - Art, Music, PE, Home Economics etc. In some schools, subjects like Music disappeared altogether and over 60 per cent of the pupils' timetable was devoted to Languages (English and Chinese), Mathematics and Science (Morris, 1997). At the institutional level the system whereby the government inspected schools was designed to focus on matters of bureaucratic and administrative compliance with regulations. Essentially there was no effective system to encourage quality assurance at either the level of schools or 
individual teachers.

The post-handover period has been characterized by a far greater concern for developing and implementing educational reform policies designed to improve the quality of schooling. To achieve this has required not only a completely new curriculum framework and the implementation of its longstanding policy on medium of instruction, but also a focus on matters of accountability and quality assurance, especially as they relate to the capabilities and qualifications of teachers. Some of the key manifestations of the increased focus on implementing educational reforms include the requirement from 1998 that all but 114 secondary schools use Chinese as the medium of instruction and, from 2002, the reduction of the bandings of pupils' academic abilities from five to three (pupils are allocated to secondary schools based upon their banding).

The period since the handover has also seen a number of significant measures designed to both enhance the status of the teaching profession and/or introduce measures designed to allow the government to regulate teachers. Key measures proposed or the actions taken include the following:

- In 1997 the Chief Executive announced in his Policy Address that in future 
all new primary and secondary school teachers would be graduates and professionally trained. From 2002 all sub-degree teacher education courses (except in the area of early childhood education) have been closed down and thus all future primary and secondary teachers will be graduates. However, the requirement that all new teachers be professionally trained is not part of the current policy agenda.

- In 2000 the government stipulated that all new kindergarten teachers would have to undertake at minimum a Qualified Kindergarten Teacher's course by 2003/04, which involves a period of study of one year. Before 2001/02, the minimum entry requirement was only two passes in the Hong Kong Certificate of Education Examination (HKCEE) taken at the end of Secondary Five, including one language subject. After 2001/02, this was raised to five passes, including two language subjects.

- In 2000 the government introduced a requirement that teachers of English and Putonghua, who were not exempted by virtue of having done a first degree and a Postgraduate Diploma in Education in the language they taught, had to pass a language proficiency attainment test (LPAT). This measures their competency in five areas (Reading, Writing, Listening, Speaking and Classroom Language Assessment). In 2003, out of the 643 serving English 
teachers who had joined the teaching force in 2001/02 and were required to take the test, 333 failed and their schools will either have to redeploy them to teach other subjects or dismiss them. Whilst there are a range of controversies concerning the nature of the assessment - especially with regard to its difficulty level, the need to pass in five discreet areas and the fact that some native English-speaking teachers have also failed the test - it represents the first attempt in Hong Kong to specify and implement a minimum level of competence for teachers of any subject.

- A report in 2003 by the Standing Committee on Language Education and Research (SCOLAR), which advises on language education, has been published to address problems related to the qualifications and proficiency of language teachers. It recommends that schools be required to only employ language teachers who majored in the language they teach and who are professionally trained. The achievement of this goal will take time, but will eventually make the LPAT unnecessary.

- The development by ACTEQ of a framework to describe the competencies expected of professional teachers.

There are major limitations and influences on these policies that arise as a result of the 
'legitimacy deficit', which refers to the situation whereby neither the colonial government nor its successor is perceived to possess a strong mandate from the people to govern. Whilst the government is able to control a majority of seats in the legislature, this is done through a series of functional constituencies. Only 24 of the 60 seats in the Legislative Council are directly elected through a system of universal suffrage, and the majority of the directly elected politicians are strongly prodemocracy and anti-government. It is notable that the largest functional constituency is for teachers and this has always elected a leading member of the Democratic Party. What emerges therefore is an elected opposition, which is perceived by the public to have a higher level of legitimacy than the government (Kuan and Lau, 2002). This deficit places limitations on the government's ability to implement unpopular policies, especially in the context of a lively civil society, a free and critical media and, in the educational policy area, a strong teachers' union. Whilst the colonial government obtained a form of legitimacy by providing (or at least operating during) a climate where people could pursue their economic self-interest, this option is far less evident since the onset of the Asian economic crisis in 1997. The post-handover government has instead attempted to achieve some legitimacy by demonstrating its commitment to reforming/improving key areas of social policy such as education and housing. 
In parallel a key element of the government's focus on educational reform has also involved creating a climate of heavy-duty criticism of the prevailing educational system as a prelude to introducing new policies. Thus longstanding features of the system, especially its exam-oriented nature, the competitive culture and the focus on discrete academic subjects, have all become the object of government-led ridicule and derision within which teachers are often portrayed as the key source of the problems. Thus: the undesirable features of pedagogy, pupils perceived declining language proficiency, and the problems encountered in implementing the curriculum reforms have all been portrayed as the direct fault of individual teachers and/or the providers of teacher education. The fact that many teachers were untrained, not teaching the subject they specialized in or they only had two or three years of sub-degree level preparation education and that this was government's policy was conveniently ignored. The overall negative climate as to the nature of schooling which emerged was highly conducive to the government introducing the range of measures described above to directly evaluate, monitor and control teachers.

There has also been a great deal of reluctance in government to see the HKIEd upgraded to a self-accrediting, university-level institution despite recommendations (The Report of the Teaching and Learning Quality Process Review Panel, 2003) that 
its current status be upgraded. The motives for this seem to derive from a combination of concerns. If the HKIEd were to become a university-level institution, then this would limit the government's capacity to control its activities and perhaps dilute the role it plays as a convenient scapegoat for the ongoing problems of schooling and teacher professionalism specifically. Ultimately, any upgrading of the HKIEd could also be at odds with the government's preference for promoting the professionalism of teachers rather than the professionalization of teaching.

The most notable and contentious accountability measure was that designed to assess the language proficiency of teachers of English and Putonghua. The quality of language teaching in Hong Kong, especially in English, has been a very longstanding problem with public concern over perceived declining standards. It was evident that many teachers who taught English had serious difficulty in terms of their own language proficiency. The reasons for this have long roots and include many of the systemic features outlined previously: the large majority of teachers in English are either untrained or have not studied the language in their own undergraduate programmes; in primary schools until recently, teachers were prepared through a twoyear sub-degree programme and they were prepared to teach three school subjects, one of which was English; and finally given the shortage of qualified English teachers 
and the massive amount of time it takes up in pupils' timetables, many teachers who specialised in teaching other subjects such as Art, Music, PE were often required to take English lessons.

Potentially the most substantive initiative, designed to have a direct impact on the teaching profession and potentially on their accountability, is the ongoing exercise to plan a 'Teacher Development Progress Map' or, as it was previously termed as a 'Generic Teacher Competency Framework'. This task is being undertaken by ACTEQ and its key features are that it is:

- Premised on the assertion that the success of reforms and quality of education are dependent on the existence of a highly professional teaching force

- Illustrative, and designed to describe the unique characteristics of the profession in ways that would allow teachers and schools to determine their own continuing professional development needs

- Derived from a model developed in an innovative local school and feedback from ten reference schools that were interested in the task

- Based upon a matrix that identifies four core dimensions (teaching and learning, student development, school development, and service to the profession and the community) which are described with reference to different stages of professional development (from competent to accomplished) 
- Designed to be used generically (not mechanically) and that overall emphasis should be given to the moral dimension of teaching, the role of collaboration and the impact of teachers on pupils' learning.

To date the absence of any clear statement as to what is expected of teachers has created a vacuum that has been filled by administrative and bureaucratic criteria. This exercise thus potentially represents a significant step forward in the professionalization of teaching. It also provides a framework against which processes of accountability can be developed - at the individual, institutional and systemic levels. If the framework generates the debate and reflection amongst the professional community that it desires and deserves, then it will serve an important function.

However, there is a range of dilemmas that will have to be recognised and addressed if it is going to have a more significant impact than its precursor, the Professional Code for Education Workers. The key issues include the following:

- The focus on the responsibility for the level of professionalism as dependent on individual teachers and schools is in marked contrast to the absence of any recognition of the responsibilities of the government. Most notable amongst these is the need for the establishment of minimum entry requirements for new 
teachers and the continued low status of the main teacher education provider.

- Whilst the framework is designed to encourage schools to develop their own models of teachers' professional development needs, there seems to be an expectation that these should be compatible with and derived from the generic framework.

- It is likely that the limited extent of consultation and involvement by the professional community for teachers and the central role of the government in developing the framework will result in the emergence of a bureaucratic approach and a high degree of suspicion by teachers. During a period of declining demand for teachers due to changes in demographics, this suspicion will be fuelled by the concern that the framework will be used, despite it not being thus intended, to make decisions about promotions, contract renewals and redundancies.

- The government's desire to use the framework to promote a strong profession characterized by a strong moral dimension is undermined by its tendency to constantly criticize teachers, to judge their quality on unidimensional criteria, especially their academic credentials, and its attempts to keep teacher education as a low status activity operating on the fringes of the higher education system. 
It is too early to determine the impact and fate of this initiative, but the critical tensions are already apparent.

\section{The government: legitimacy and capacity}

The strategies, or more accurately the initial absence of any strategies, to hold teachers accountable, the parallel maintenance of a low level of professionalization and the current attempts by the post-handover government to develop systems to regulate teachers can be understood with reference to the legitimacy deficit, discussed earlier and two further considerations:

- There is the degree of determination by the government to actually implement changes designed to improve and reform schools. This recognises that policies can serve purposes other than describing a concrete blueprint for change and action. They can also serve an essentially symbolic function whereby policy is designed to primarily demonstrate the government's recognition of and concern for a problem, but a change from the status quo is not the core objective (Morris and Scott, 2003). The best illustration of this was the policy of the Medium of Instruction. Since the late 1970s, government's stated policy was to promote instruction in pupils' mother tongue (Cantonese) but not until after 1997 was the policy implemented.

- There is the extent to which the government has the capacity to carry out 
educational reforms. Whilst it has been extremely successful in implementing infrastructure projects, that involve the distribution of public goods such as housing and schooling, it has proven far less successful in delivering qualitatively focused reforms such as those which are designed to improve the quality of teaching and learning.

In the pre-handover period, the combination of the above conditions seemed to result in a tendency for the colonial government to focus on expanding provision and the promotion of a range of essentially symbolic educational policies designed to improve the quality of education. When policies were pursued and resistance or implementation problems emerged, there was a distinct tendency to allow the status quo to prevail in an attempt to avoid conflict. Also, when instability or social conflict between the government and the community emerged, such as in the mid 1950s and mid 1960s, access to different levels of education was sequentially expanded as a way of buying public support. Thus the expansion of primary, secondary and subsequently tertiary education all coincided with periods of political discontent or social turmoil (Morris, 2002).

The post-handover government has faced an acute problem vis-à-vis legitimacy, 
especially given the cumulative effects of the Asian economic crisis, the aftermath of ' $9 / 11$ ', the SARS crisis and most recently, on the 1 st of July 2003 , the enormous demonstration against notional security legislation - all of which have affected its ability to provide a stable economic climate. It has also not been able to benefit from expanding the distribution of public goods (e.g. housing and transportation) as these have already been provided on a mass level and resources are no longer plentiful. Consequently, in the eyes of the community, it has not had the economic or performance legitimacy that the colonial government benefited from. In parallel, the post-handover government has, of necessity rather than choice, been far more determined to be seen to improve key areas of social policy and rely less on symbolic policy measures. The result is a greater potential for conflict as a government with a low level of legitimacy and a higher degree of determination to pursue change in the context of a depressed economy and significant budget deficit.

A further consideration, which has been specific to the post-handover government, is what Scott (2001) has termed the problem of 'disarticulation'. This refers to the fragmentation of and competition between the various components of the policymaking community. Under the colonial government what was presented to the public was a relatively coherent and unified set of policies, which the civil service 
promoted and defended. This is not to suggest that dissent or conflict were absent. But generally, conflicts between and within the policy-making community were not open to public scrutiny.

Since 1997 this unity and coherence has disappeared as a range of new centres of power outside the traditional policy making community have emerged and the civil service itself has been portrayed as a policy problem - being deemed insufficiently loyal, over-manned and overpaid. Thus in 2002 a set of 11 Ministers were appointed from outside the civil service to head the key ministries. The result is that the source and nature of policies has become fuzzy and contested as various groups attempt to define and redefine policies. The International Monetary Fund (IMF) noted this in June 2003, when it criticised as confusing the system of overlapping ministerial responsibilities.

The 'all graduate, all trained' policy for teachers was one example of a lack of coherence (Morris and Scott, 2003). It was promulgated by the Chief Executive in 1997, but has been subsequently reinterpreted by ACTEQ to mean that new teachers should be trained soon after they obtain teaching jobs. In contrast, as previously noted, SCOLAR has recommended that all new language teachers should be 
graduates and professionally trained in the language they teach.

\section{$\underline{\text { Conclusion }}$}

The key feature that has emerged from this analysis of teacher accountability in Hong

Kong is the extent to which it has been strongly interconnected with both the role of the state and the professionalization of teaching.

Initially the level of both professionalization and accountability (of either the internal or external variety) was low. This situation suited a colonial government with a low level of legitimacy that was wary of the emergence of a strong and unified teaching force. Consequently, later attempts from within the teaching community to develop a framework for self-regulation were neutralized by the state.

In contrast the post-handover period has been notable for the government's attempts to enact measures ostensibly designed to intensify the external scrutiny of teachers and to professionalize teaching. However, whilst many of these new policies address areas long neglected, there are a number of considerations that will determine their impact. The first relates to the perennial problem of the locus of control of power and the government's innate unwillingness to relinquish its control and continuing ambivalence to a professionalized teaching force. There are no signs that what is 
envisaged will involve the profession being given (or even share) the power to regulate itself and its reluctance to upgrade the main teacher education provider.

Secondly, the increasingly tenuous legitimacy of the government will affect both its approach to teachers and their response. Clearly the government's role in the professionalization of teaching and the emergence of appropriate systems of accountability, especially insofar as these relate to the profession regulating itself, will remain critical. However in other areas, such as the minimum entry requirements for new teachers and the removal of barriers to the upgrading of the HKIEd, there is more potential for the government to support its own rhetoric concerning teacher professionalism.

In effect what has emerged is that the government has highlighted the importance of teachers behaving as professionals and this has been used as a platform for government to control the process of professionalization. Consequently its own insecurity and tendency to bureaucratic solutions has ensured an approach that has actually limited the professionalization of teaching.

Clearly the government's role in the development of a professional teaching force and 
of effective measures of accountability will be constrained while its legitimacy remains tenuous. Specifically, we can anticipate that this will serve to ensure its reluctance to see the emergence of a self-regulating profession. However, in other areas, such as the expectation that new teachers be professionally trained and the removal of barriers to upgrading of the HKIEd, there is more potential for the government to support the professionalization of teaching in Hong Kong.

\section{$\underline{\text { References }}$}

Brown, D.J. (1990). Decentralization and School-based Management. London: Falmer Press.

Cheng, K.M. \& Wong, S.Y. (1997). Empowerment of the Powerless Through the Politics of the Apolitical: Teacher Professionalism in Hong Kong. In B.J. Biddle et al (eds.), International Handbook of Teachers and Teaching. Netherlands: Kluwer Academic Publishers.

Cheung, E. (2001). Hong Kong Secondary School Teachers' Understanding of Their Careers. Unpublished PhD thesis, The University of Hong Kong Code for the Education Profession of Hong Kong (1990). Hong Kong: Preparatory Committee, Professional Code for Educational Workers.

ECR2 (1986). Education Commission Report No. 2. Hong Kong: Government Printer. 
ECR5 (1992). Education Commission Report No. 5. Hong Kong: Government Printer.

Eraut, M. (1994). Developing Professional Knowledge and Competence. London \&

Washington DC: Falmer Press.

Etzioni, A. (1969). The Semi-Professions and their Organization: Teachers, Nurses,

Social Workers. New York: Free Press.

Holmes Group (1986). Tomorrow's Teachers. East Lansing, MI: The Holmes Group.

Ingvarson, L. (2000). Teacher Control and the Reform of Professional Development.

In H. Altrichter \& J. Elliott (Eds.), Images of Educational Change. Buckingham \& Philadelphia: Open University Press.

Jones, G.W. (1992). The Search for Local Accountability. In S. Leach (Ed.), Strengthening Local Government in the 1990s. London: Longman.

Kuan, H.C. \& Lau, S.K. (2002). Between Liberal Autocracy and Democracy: Democratic Legitimacy in Hong Kong. Democratization, Vol. 9, No. 4, pp. 5876.

Lai, K.C., Ko, K.W. \& Li, C. (2001). Profile of the Teaching Profession in Hong Kong in the 1990s (update of Teacher Education Planning Digest, Issue 5). Hong Kong: Office of Planning and Academic Implementation, The Hong Kong Institute of Education.

Larson, M.S. (1977). The Rise of Professionalism: A Sociological Analysis. Berkeley \& Los Angeles: University of California Press. 
Lo, M.L. (2002). A Tale of Two Teachers - Teachers Responses to an Imposed Curriculum Reform. Teacher Development: An International Journal of Teachers' Professional Development. Volume 6, No.1, p.33-46.

Lo, M.L. (2000). Learning Without Tears: The Relativity of a Curriculum Reform and its Impact. In Adamson, B., Kwan, T and Chan, K.K., Changing the Curriculum: The Impact of Reform on Primary Schooling in Hong Kong. Hong Kong: Hong Kong University Press. P.47-80.

Morris, P. (1996). The Hong Kong School Curriculum: Development, Issues and Policies. $2^{\text {nd }}$ Edition. Hong Kong: Hong Kong University Press.

Morris, P. (1997). School Knowledge, the State and the Market: an Analysis of the Hong Kong Secondary School Curriculum. Journal of Curriculum Studies, Vol. 29, No. 3, pp. 329-349.

Morris, P. (2002). Promoting Curriculum Reforms in the Context of a Political Transition: an Analysis of Hong Kong's Experience. Journal of Education Policy, Vol. 17, No. 1, pp. 13-28.

Morris, P. \& Scott, I. (2003). Educational Reform and Policy Implementation in Hong Kong. Journal of Education Policy, Vol. 18, No. 1, pp. 71-84.

Morris, P \& Williamson, J. (Eds.) (2000). Teacher Education in the Asia-Pacific Region: a Comparative Study. New York \& London: Falmer Press.

Mulgan, R. (2000). ‘Accountability': An Ever-expanding Concept? Public 
Administration, Vol. 78, No. 3, pp. 555-573.

Report of the Teaching and Learning Quality Process Review Panel (2003)

SCOLAR (2003). Action Plan to Raise Language Standards in Hong Kong - Final Report of Language Education Review. Hong Kong: Standing Committee on Language Education and Research.

Scott, I. (2001). The Disarticulation of Hong Kong's Post-handover Political System. China Journal, Vol. 43, pp.29-53

Sweeting, A. (1993) A Phoenix Transformed: The Reconstruction of Education in Post-war Hong Kong. New York: Oxford University Press

Visiting Panel (1982). A Perspective on Education in Hong Kong: Report by a Visiting Panel. Hong Kong: Hong Kong Government.

\section{$\underline{\text { Acknowledgement }}$}

The author is very grateful for the help and advice of Esther Morris, John Elliott, Ian Scott, Tony Sweeting and Lai Kwok Chan. Of course they are not responsible for the views expressed. 